\title{
Physical modelling of reinstallation of a novel spudcan nearby existing footprint
}

\author{
M.J. Jun, Y.H. Kim, M.S. Hossain, M.J. Cassidy \\ Centre for Offshore Foundation Systems, The University of Western Australia, Perth, WA, Australia
}

$\mathrm{Y} . \mathrm{Hu}$

School of Civil, Environmental and Mining Engineering, The University of Western Australia, Perth, WA, Australia

\section{S.G. Park}

Daewoo Shipbuilding \& Marine Engineering Co. Ltd., Seoul, Korea

\begin{abstract}
The interaction between a spudcan and an existing footprint is one of the major concerns during jack-up rig installation. When a spudcan is located on or nearby an adjacent footprint slope, there is a tendency for the spudcan to slide towards the centre of the footprint, inducing excessive lateral forces and bending moments to the rig. Adverse spudcan displacement could result in an inability to install the jack-up in the required position, leg splay, structural damage to the leg, and at worst, bumping or collapsing into the neighboring operating platform. This paper reports the results from a series of $1 \mathrm{~g}$ and centrifuge model tests investigating spudcan-footprint interactions in clay. Three footprint shapes were tested varying depth and diameter. The footprints were generated using a cutting tool, and for the deep vertical walled footprints in the centrifuge, a plastic collar was pioneered to ensure footprint stability before testing. Spudcan loads during reinstallation were measured using a vertical load cell and two bending gauges. A novel spudcan, which was developed to minimise the interaction effects, was also tested and compared the responses with those of a generic spudcan. The results from this study indicated that the novel spudcan has potential to ease spudcan-footprint interactions.
\end{abstract}

\section{INTODUCTION}

Most offshore drilling in shallow to moderate water depths $(<150 \mathrm{~m})$ is performed from self-elevating jack-up rigs due to their proven flexibility, mobility and cost-effectiveness (CLAROM 1993; Randolph et al. 2005). Today's jack-ups typically consist of a buoyant triangular platform supported by three independent truss legs, each attached to a large 10 to $20 \mathrm{~m}$ diameter spudcan. After the completion of the task, the legs are retracted from the seabed, leaving depressions at the site (referred to as a 'footprint').

Jack-ups often return to sites where previous operations have left footprints in the seabed. This is, for example, to drill additional wells or service existing wells, repair a platform or to install new structures such as jackets or wind turbines (Killalea 2002; Osborne and Paisley 2002; InSafeJIP 2010). When a spudcan is located on or nearby an adjacent footprint slope, there is a tendency for the spudcan to slide towards the centre of the footprint, inducing excessive lateral forces and bending moments to the rig (see Fig. 1). Hazards include an inability to install the jack-up in the required position, leg splay, structural damage to the leg, and at worst, bumping or collapsing into the neighbouring operating platform. The frequency of offshore incidents during installation near footprints has increased by a factor of four between the period 1979 88 and 1996 06 (Osborne 2005) and at an even higher rate over 2005 2012
(Jack et al. 2013), with examples of offshore incidents also documented by Hunt \& Marsh (2004), Brennan et al. (2006) and Handidjaja et al. (2009).

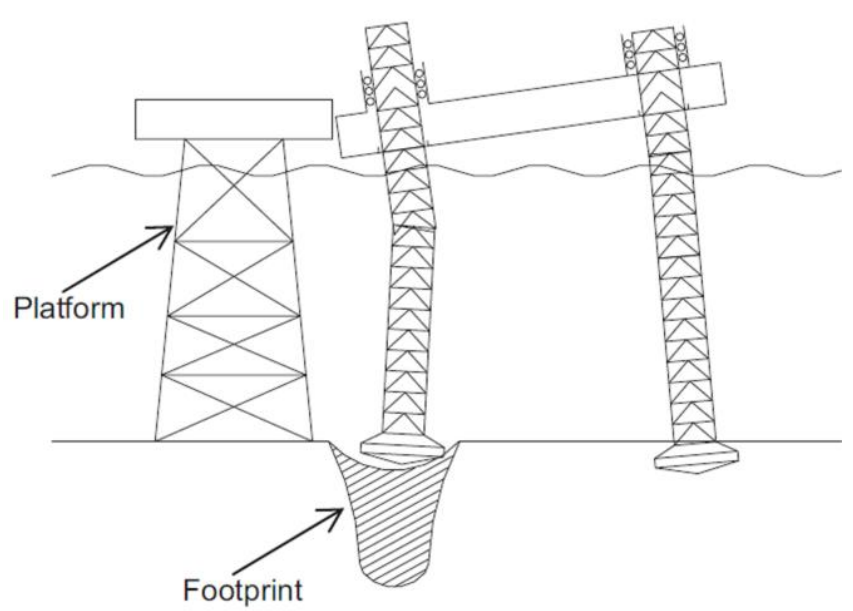

Figure 1. Spudcan reinstallation near footprint (after Kong et al. 2013).

Penetration of spudcan foundations next to footprints has been addressed by a number of researchers, with each concentrating on a particular geometric aspect of the problem, such as the offset of reinstallation or the influence of the testing fixity conditions during reinstallation (e.g. Gaudin et al. 2007; Leung et al. 2007; Gan et al. 2008 \& 2012; Cassidy et al. 2009; Kong et al. 2013). However, a minimum attention has been paid to mitigating spudcan-footprint interaction issues. In the field, 
stomping and successive leg repositioning (Brennan et al. 2006) and water jetting with the spudcan preloading (Handidjaja et al. 2009) have been used. Alternatively this study focuses on the shape of the spudcan itself and whether the shape can be manipulated to mitigate the effects of reinstallation adjacent to a footprint. A novel spudcan shape, developed to ease the footprint interactions through a series of large deformation finite element analysis (Jun et al. 2017a \& b, 2018), is compared experimentally against the response of a generic spudcan at $1 \mathrm{~g}$ and $200 \mathrm{~g}$ conditions. Footprint geometries were varied by changing the diameter and depth, following the technique manually cutting a footprint into the sample (of Kong et al. 2013) and extending it to allow deep footprints with vertical walls to be tested.

\section{MODEL TEST}

\subsection{Experimental program and sample preparation}

The experimental programme comprised $1 \mathrm{~g}$ and $200 \mathrm{~g}$ modelling of penetration of spudcans nearby footprints. The spudcan tests were performed on three boxes of single layer samples of kaolin clay, with the geotechnical properties given in Table 1. A homogeneous slurry was prepared by mixing commercially available kaolin clay powder with water at $120 \%$ water content (twice the liquid limit). The slurry was then poured in beam rectangular strongboxes, which has internal dimensions of 650 (length) $\times 390$ (width) $\times 325$ (depth) $\mathrm{mm}$. The soil samples were then pre-consolidated gradually on the high capacity press under a final pressure of 100, 200 and $550 \mathrm{kPa}$ (see Table 2).

Table. 1 Main properties of kaolin clay (after Stewart 1992).

\begin{tabular}{ll}
\hline Properties of kaolin clay & Value \\
\hline Specific gravity, $G_{\mathrm{s}}$ & 2.6 \\
Angle of internal friction, $\phi^{\prime}$ (degree) & 23 \\
Critical state frictional constant, M & 0.92 \\
Liquid limit, LL $(\%)$ & 61 \\
Plastic limit, PL $(\%)$ & 27 \\
Plasticity index, $\mathrm{I}_{\mathrm{p}}(\%)$ & 34 \\
\hline
\end{tabular}

Soil characterisation tests were carried out using a T-bar penetrometer, of diameter $5 \mathrm{~mm}$ and length $20 \mathrm{~mm}$. Typical shear strength $\left(\mathrm{s}_{\mathrm{u}}\right)$ profiles for the three samples are shown in Figure 2, based on a T- bar deep bearing capacity factor of $\mathrm{N}_{\mathrm{T} \text {-bar }}=10.5$ (where $\mathrm{z}$ is the penetration depth of the T-bar middiameter and $\mathrm{D}$ is the spudcan diameter).

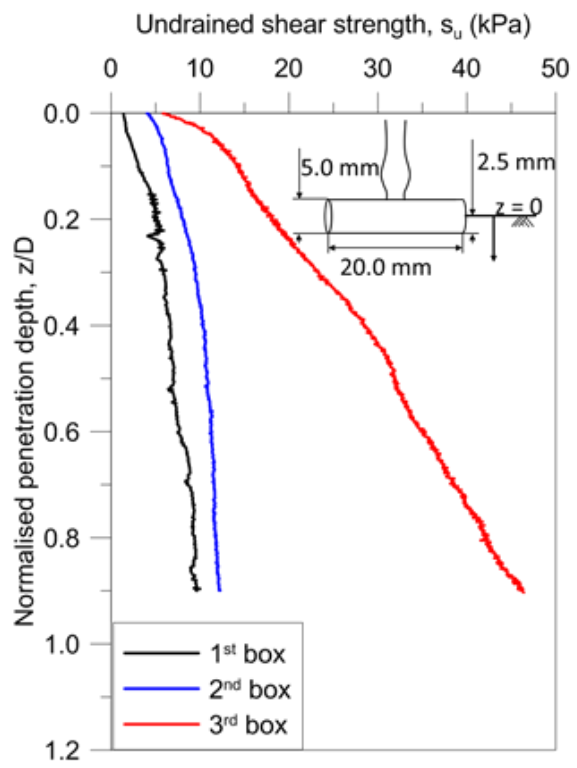

Figure 2. Undrained shear strength profile measured by $\mathrm{T}$ bar penetrometer

\subsection{Model spudcan}

Two different spudcan models of $60 \mathrm{~mm}$ diameter; (a) generic spudcan and (b) novel spudcan; were used, with their shape shown in Figure 3. The generic spudcan shape was chosen similar to the spudcans of the 'Marathon LeTourneau Design, Class 82SDC' jack-up rig, as illustrated by Menzies \& Roper (2008). A novel spudcan to minimise the horizontal force and moment induced by the interaction was developed. The basic shape of the novel spudcan is similar to the generic spudcan. However, the underside profile has been flattened and four evenly spaced holes (each of $14.4 \mathrm{~mm}$ diameter) inserted vertically between the spudcan top and base (see Fig. 3b). The role of each geometric factor was explored through large deformation finite element (LDFE) analyses by Jun et al. (2017a \& b, 2018), and compared with the experimental results in a latter section of this paper.

Figure 4a shows the experimental set-up, including the spudcan, vertical load cell and bending leg used. The spudcan was rigidly connected to a model leg made from duraluminium. The leg was instrumented by two sets of bending strain gauges and one

Table 2. Summary of experimental tests

\begin{tabular}{|c|c|c|c|c|c|c|c|c|}
\hline \multirow[t]{2}{*}{ Box } & \multirow[t]{2}{*}{ Tests } & \multirow[t]{2}{*}{ Test $\mathrm{g}$ level } & \multirow[t]{2}{*}{ Spudcan shape } & \multicolumn{2}{|c|}{ Footprint shape } & \multirow{2}{*}{$\begin{array}{l}\text { Pre-consolidation } \\
\text { pressure }(\mathrm{kPa})\end{array}$} & \multirow{2}{*}{$\begin{array}{l}\text { Offset distance, } \\
\beta\end{array}$} & \multirow[t]{2}{*}{ Note } \\
\hline & & & & $\mathrm{D}_{\mathrm{F}}$ & $\mathrm{Z}_{\mathrm{F}}$ & & & \\
\hline 1 & $\begin{array}{l}\text { Test } 1 \\
\text { Test } 2\end{array}$ & $1 \mathrm{~g}$ & $\begin{array}{l}\text { Generic } \\
\text { Novel }\end{array}$ & $1.0 \mathrm{D}$ & $0.42 \mathrm{D}$ & 100 & $0.50 \mathrm{D}$ & Deep footprint \\
\hline 2 & $\begin{array}{l}\text { Test } 3 \\
\text { Test } 4\end{array}$ & $200 \mathrm{~g}$ & $\begin{array}{l}\text { Generic } \\
\text { Novel }\end{array}$ & $2.0 \mathrm{D}$ & $0.33 \mathrm{D}$ & 200 & $0.55 \mathrm{D}$ & Shallow footprint \\
\hline 3 & $\begin{array}{l}\text { Test } 5 \\
\text { Test } 6\end{array}$ & $200 \mathrm{~g}$ & $\begin{array}{l}\text { Generic } \\
\text { Novel }\end{array}$ & $1.0 \mathrm{D}$ & $0.50 \mathrm{D}$ & 550 & $0.50 \mathrm{D}$ & Deep footprint \\
\hline
\end{tabular}



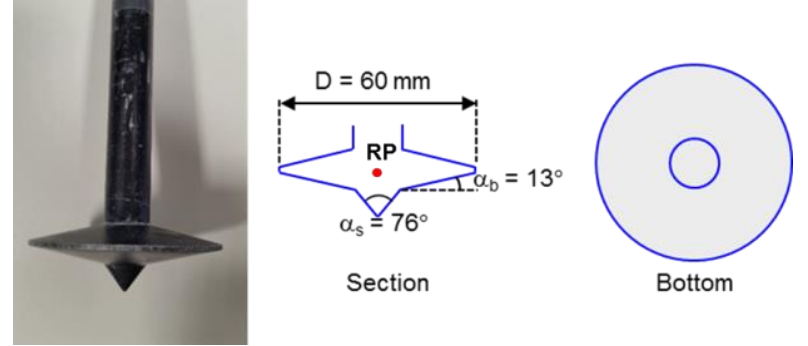

(a) Generic spudcan
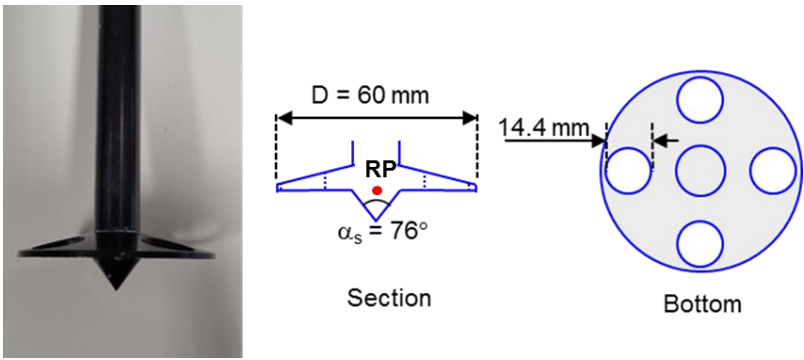

(b) Novel spudcan

Figure 3. Spudcan shapes: (a) Generic spudcan; (b) Novel spudcan.

load cell to record the horizontal force, bending moment and vertical resistance generated during testing. The model leg was mounted on the strongbox with an actuator (see Fig. 4b). Note, in the field, the bending response of the truss leg is dictated by its stiffnesses and the connection of the leg to the hull. In this study, the tests were performed considering a fixed head boundary condition at the top level of leg, leading to a condition with very high leg stiffnesses, which is somewhat consistent with ISO (2012).

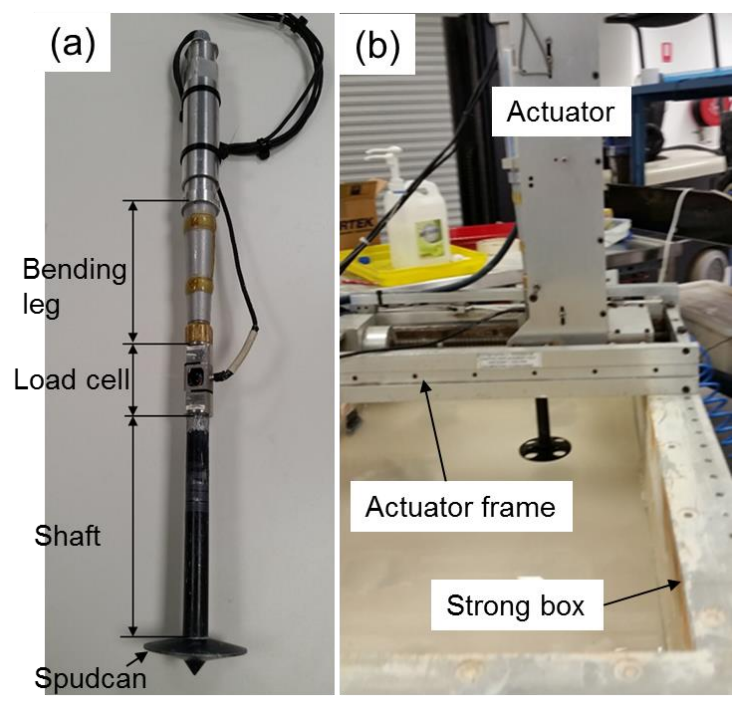

Figure 4. Experimental setup to measure the responses of footprint-spudcan interactions (a) Spudcan, shaft and model leg; (b) Experimental setup.

The T-bar and spudcan tests were carried out at a rate of $1 \mathrm{~mm} / \mathrm{s}$ and $0.19 \mathrm{~mm} / \mathrm{s}$, respectively, targeting a non-dimensional velocity index of $\mathrm{V}_{\mathrm{p}}=\mathrm{vD}_{\mathrm{e}} / \mathrm{c}_{\mathrm{v}}$ $>30$ (where $\mathrm{v}$ is the penetration velocity, De is the area equivalent diameter) to ensure undrained conditions in the kaolin clay with $\mathrm{c}_{\mathrm{v}} \approx 2.6 \mathrm{~m}^{2} /$ year (Finnie \& Randolph, 1994; Cassidy, 2012).

\subsection{Artificial footprint generation}

Artificial footprints were generated on the surface of the pre-consolidated samples. A cutting tool comprised of a mounting frame and cutting blades was developed to create the footprint cavity (see Fig. 5). The frame was first mounted on the strongbox and the cutting blade was then rotated and cut into the soil forming a cavity of ideal conical shape until the desired footprint depth was reached. With this cutting method, the disturbance of the adjacent soil around and beneath the artificial footprint was minimal. This was shown by Kong (2012) and Kong et al. (2013) who used a similar experimental cutting technique".

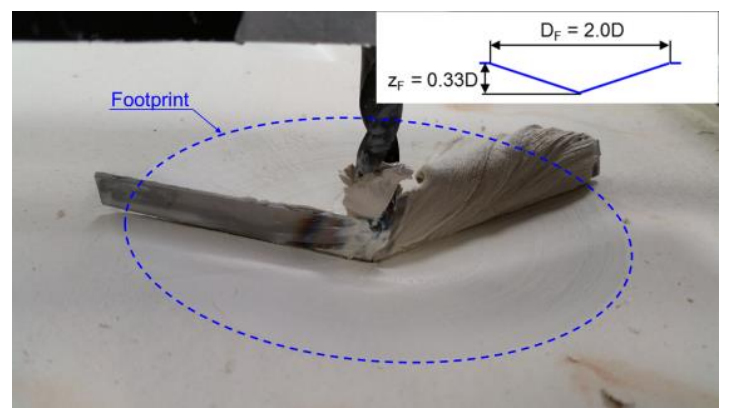

(a) Shallow footprint

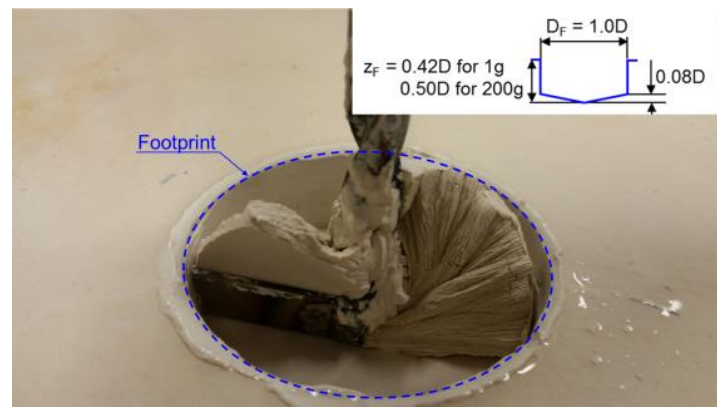

(b) Deep footprint

Figure 5. Artificial footprint generation by using two types of cutting tools: (a) Shallow footprint; (b) Deep footprint.

Depending on their sensitivity, natural fine grained soil deposits experience a degree of remoulding through the spudcan penetrationextraction event. This disturbance is recovered gradually with time through dissipation of excess pore pressure. For the kaolin clay used in the centrifuge tests in the vicinity of the footprint, it took $1 \sim 1.5$ years to recovery its full strength, though of course this is a function of the soil's permeability (Leung et al. 2007). The strength recovery of the clay along and adjacent to a footprint was shown as a function of elapse time after the spudcan extraction by plotting strength contours (Gan et al., 2012) measured in the centrifuge. Because of the complexity and variety of possible soil strength gradients around the footprint (see contours of Gan et al. 2012), an artificial footprint was created in this study, where the soil strength along and adjacent to the footprint was identical to the intact strength profile. This simpli- 
fied soil strength profile allows a consistent evaluation of the benefits of the spudcan shape.

From the results of a series of centrifuge tests, Hossain and Dong (2014) concluded that a conical footprint of depth $\mathrm{z}_{\mathrm{F}}=0.22 \sim 0.33 \mathrm{D}$ was formed in soft clay whilst a cylindrical flat-based footprint of depth $\mathrm{z}_{\mathrm{F}}=0.5 \sim 0.66 \mathrm{D}$ was formed in stiff clay. These findings are consistent with footprints measured in Gan et al. (2008), Teh et al. (2010), and Erbrich et al. (2015). In this study, the depth of the toe of the footprint $\mathrm{z}_{\mathrm{F}}$ was varied $0.33 \mathrm{D}$ to $0.5 \mathrm{D}$, and the width of the footprint $\mathrm{D}_{\mathrm{F}}$ as 1 2D. The details of the investigated footprint geometries are summarised in Table 2.

\subsection{Experimental cases}

The spudcan was penetrated near the artificial footprint. The offset distance $(\beta)$ from the footprint centre to the spudcan centre was $0.55 \mathrm{D}$ for the shallow footprint and $0.50 \mathrm{D}$ for the deep footprint. This offset was tested as it was identified as producing the largest induced loads on the spudcan by Kong et al. (2013) and Zhang et al. (2015). The experimental cases are summarised in Table 2.

\section{RESULTS AND DISCUSSION}

The effect of the novel spudcan shape (see Fig. 3b) at mitigating spudcan-footprint interactions has been evaluated through comparison with the performance of the generic spudcan shape. For direct comparison, avoiding the influence of the various undrained shear strength $\left(\mathrm{s}_{\mathrm{u}}\right)$ profiles, all the response profiles were normalised using the measured soil strength $\left(\mathrm{s}_{\mathrm{u}}\right)$, spudcan full plan area $\mathrm{A}\left(=0.0028 \mathrm{~m}^{2}\right.$ for $1 \mathrm{~g}$ test and $113.1 \mathrm{~m}^{2}$ for $200 \mathrm{~g}$ tests) and spudcan diameter (D). To maintain the form of the response profiles, $s_{u}$ at a fixed depth was used for normalising horizontal force $(\mathrm{H})$ and moment $(\mathrm{M})$, while full $\mathrm{s}_{\mathrm{u}}$ profile was used for normalising vertical force $(\mathrm{V})$. $\mathrm{s}_{\mathrm{u}}$ at a fixed depth of half of the footprint depth $\left(0.5 z_{\mathrm{F}}\right)$ was selected to represent the soil strength over the footprint depth. Table 3 shows an example of the difference in normalisation using $\mathrm{s}_{\mathrm{u}}$ full profile and $s_{u}$ at the fixed depth of $0.5 z_{F}$.

Table 3. Example of normalisation of $\mathrm{H}_{\max }$ with $\mathrm{s}_{\mathrm{u}} \mathrm{vs} \mathrm{s}_{\mathrm{u}, 0.5 \mathrm{zF}}$.

\begin{tabular}{llll}
\hline & Generic & Novel & $\begin{array}{l}\text { Reduction using } \\
\text { novel spudcan }\end{array}$ \\
\hline $\mathrm{H}_{\max }(\mathrm{N})$ & 13.2 & 7.8 & $40.3 \%$ \\
$\mathrm{H}_{\max } / \mathrm{As}_{\mathrm{u}, 0.5 \mathrm{zF}} *$ & 0.87 & 0.52 & $40.3 \%$ \\
$\mathrm{H}_{\max } / \mathrm{As}_{\mathrm{u}}^{\#}$ & 1.53 & 0.47 & $68.9 \%$ \\
\hline $\mathrm{As}_{\mathrm{u}, 0.5 \mathrm{zF}} \$ 15.1 \mathrm{~N}$ \\
$\# \mathrm{As}_{\mathrm{u}}=8.6 \mathrm{~N}$ for generic spudcan; $16.5 \mathrm{~N}$ for novel spudcan \\
$\$ \mathrm{~s}_{\mathrm{u}, 0.5 \mathrm{zF}}=5.3 \mathrm{kPa}$ for Test 1 and 2 \\
$7.8 \mathrm{kPa}$ for Test 3 and 4 \\
$20.3 \mathrm{kPa}$ for Test 5 and 6
\end{tabular}

\section{$3.11 \mathrm{~g}$ test with deep footprint}

Figure 6 shows the results from Test 1 and Test 2 $\left(\mathrm{D}_{\mathrm{F}}=1.0 \mathrm{D}, \mathrm{z}_{\mathrm{F}}=0.42 \mathrm{D}, \beta=0.50 \mathrm{D}\right.$; Table 2$)$ conducted at $1 \mathrm{~g}$ on the laboratory floor. The normalised horizontal force $\left(\mathrm{H} / \mathrm{As}_{\mathrm{u}, 0.5 \mathrm{zF}}\right)$, vertical force $\left(\mathrm{V} / \mathrm{As} \mathrm{s}_{\mathrm{u}}\right)$ and moment $\left(\mathrm{M} / \mathrm{As}_{\mathrm{u}, 0.5 \mathrm{zF}}\right)$ at the reference point $\mathrm{RP}$ of the spudcans (defined in Fig. 3) are presented as a function of the normalised penetration depth, $d / D$ (where $\mathrm{d}$ is the penetration depth of the largest cross section of the spudcan; see Fig. 3). By using the novel spudcan, the maximum normalised horizontal force was reduced by $40.3 \%$ of that of the generic spudcan (see Fig. 6a). This is because of the bottom profile. The flat bottom profile of the novel spudcan minimised the horizontal contact area and hence the reduced horizontal force, compared to the sloped bottom profile of the generic spudcan (see inset figures in Fig. 6a). These findings are consistent with the numerical results presented by Jun et al. (2017a).
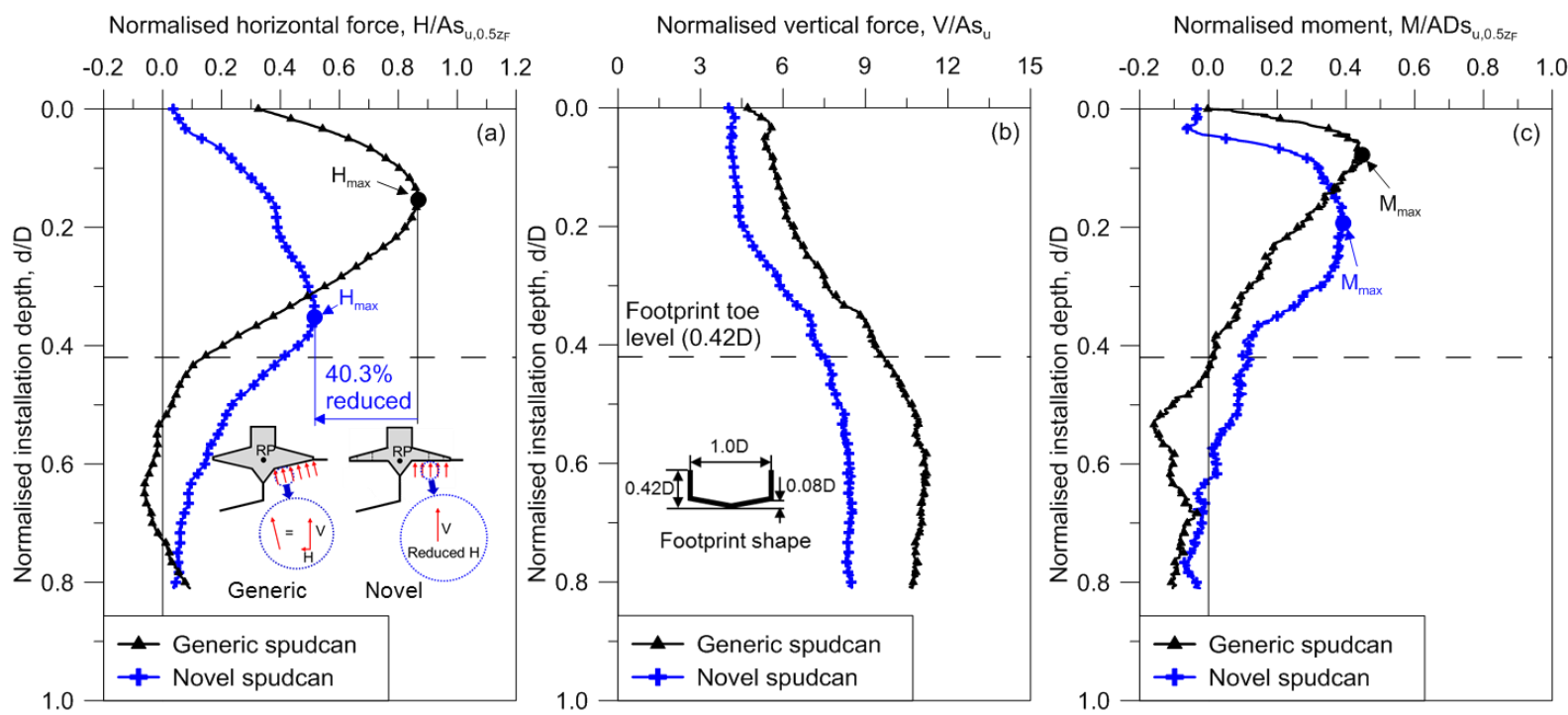

Figure 6. Responses from deep footprint shape at $1 \mathrm{~g}$ (Test 1 and Test $2 ; \mathrm{D}_{\mathrm{F}}=1.0 \mathrm{D}, \mathrm{z}_{\mathrm{F}}=0.42 \mathrm{D}, \beta=0.50 \mathrm{D}$; Table 2): (a) Normalised horizontal force; (b) Normalised vertical force; (c) Normalised moment. 

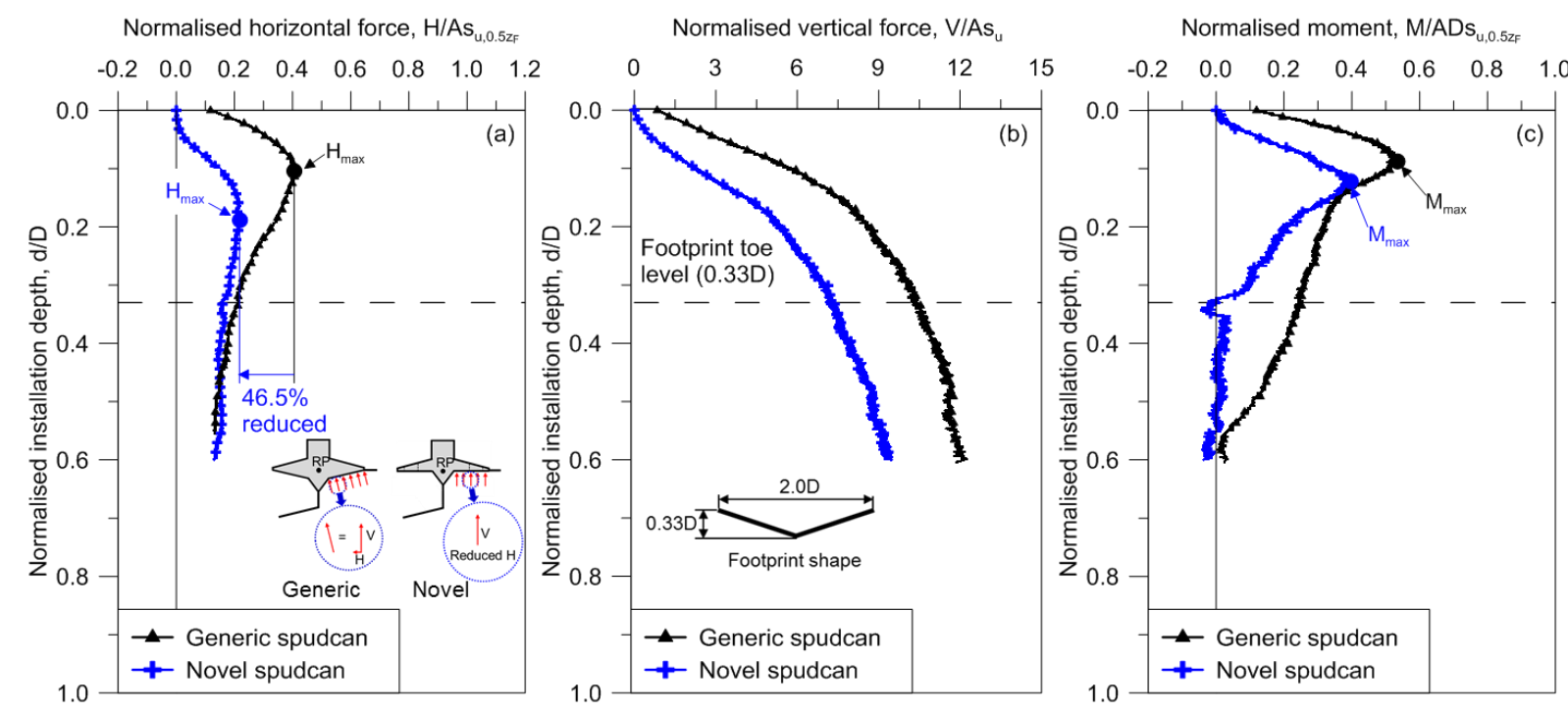

Figure 7. Responses from shallow footprint shape at 200g (Test 3 and Test 4; $\mathrm{D}_{\mathrm{F}}=2.0 \mathrm{D}, \mathrm{z}_{\mathrm{F}}=0.33 \mathrm{D}, \beta=0.55 \mathrm{D}$; Table 2): (a) Normalised horizontal force; (b) Normalised vertical force; (c) Normalised moment.

Within the tested depths, the normalised vertical response of the novel spudcan is lower than that of the generic spudcan partly because of the lower embedded volume of the foundation at $\mathrm{d}=0$ (see Fig. 3 ) and partly because the reduction in the recorded vertical load by the holes (while the full plan area A was used for normalization, although the net area was $23 \%$ lower owing to the holes). However, with the progress of penetration below the footprint toe, this gap will be diminished gradually as the soil flowing through the holes will be stopped by the pressure of the backfilled soil above the spudcan. This means the holes will be blocked and the spudcan will penetrate further as if a spudcan without holes.

The moment about the RP mainly resulted from the resultant vertical force and its eccentricity from the RP as the resultant horizontal force passes nearly through the RP (Kong et al. 2013; Zhang et al. 2015). As such, the reduced maximum moment by the novel spudcan was mainly caused by the reduced vertical force.

\subsection{Centrifuge test with shallow footprint- $200 \mathrm{~g}$}

Figure 7 shows the results from Test 3 and Test 4 $\left(\mathrm{D}_{\mathrm{F}}=2.0 \mathrm{D}, \mathrm{z}_{\mathrm{F}}=0.33 \mathrm{D}, \beta=0.55 \mathrm{D}\right.$; Table 2) conducted at $200 \mathrm{~g}$. Similar to the results from tests at $1 \mathrm{~g}$ test (Fig. 6), the novel spudcan shows a benefit in reducing horizontal force. The reduction in the maximum normalised horizontal force can be calculated as $46.5 \%$ (Fig. 7). After passing the footprint toe level $(0.33 \mathrm{D})$, the difference in horizontal force and moment between the two spudcans diminished.

\subsection{Centrifuge test with deep footprint- $200 \mathrm{~g}$}

To investigate the effect of the footprint depth $\mathrm{z}_{\mathrm{F}}$ at identical testing conditions, Test 5 and Test $6\left(\mathrm{D}_{\mathrm{F}}=\right.$ $1.0 \mathrm{D}, \mathrm{z}_{\mathrm{F}}=0.50 \mathrm{D}, \beta=0.50 \mathrm{D}$; Table 2) were carried out at 200g. For the deep footing, Test 1 and Test 2 were undertaken at $1 \mathrm{~g}$ and the craters were stable during the testing even though the undrained shear strength of the soil was low $\left(\mathrm{s}_{\mathrm{u}}=\sim 10 \mathrm{kPa}\right)$. This is because the soil overburden pressure over the footprint depth of $0.42 \mathrm{D}$ i.e. $25.2 \mathrm{~mm}$ at $1 \mathrm{~g}$ was very low. However, in a first attempt in the centrifuge, even with clay with higher $\mathrm{s}_{\mathrm{u}}$ of $\sim 55 \mathrm{kPa}$, the edge of the crater cracked and collapsed during spinning up of the centrifuge although the crater was generated with care and precision (see Fig. 8a). This was the case even though cavity collapse was not predicted for the higher overburden stress (i.e. footprint depth $0.50 \mathrm{D}$ is a prototype $6 \mathrm{~m}$ at $200 \mathrm{~g}$ ) using Rankine's pressure theory (Meyerhof, 1972) and upper-bound plasticity analysis (Britto \& Kusakabe, 1982, 1983). The main reason is believed to be that after cutting the footprint there is further swelling of the surface of the pre-consolidated sample by the sucking ambient water during centrifuge spinning. This reduced the strength of the soil close to the surface.

The lesson learnt during this initial attempt was

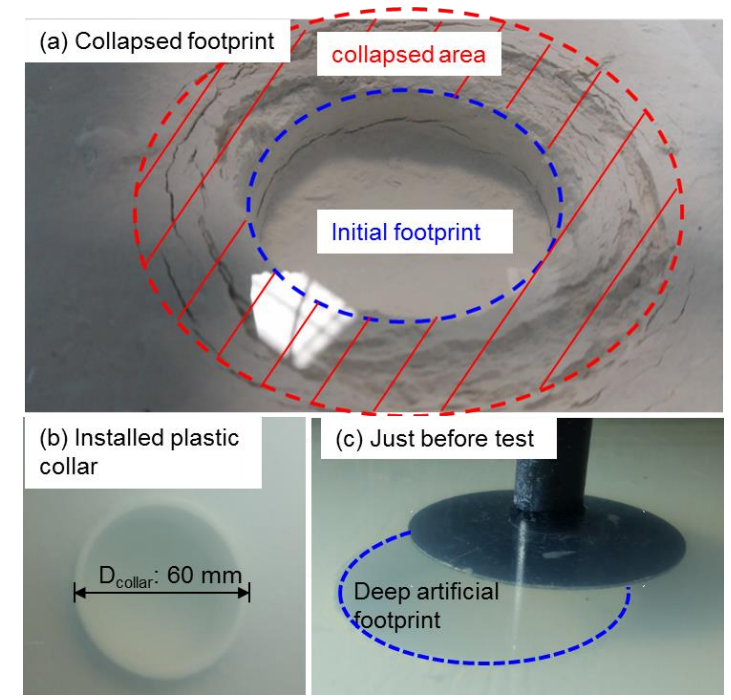

Figure 8. Deep footprint preparation: (a) Collapsed footprint; (b) Installed plastic collar (c) Just before test. 


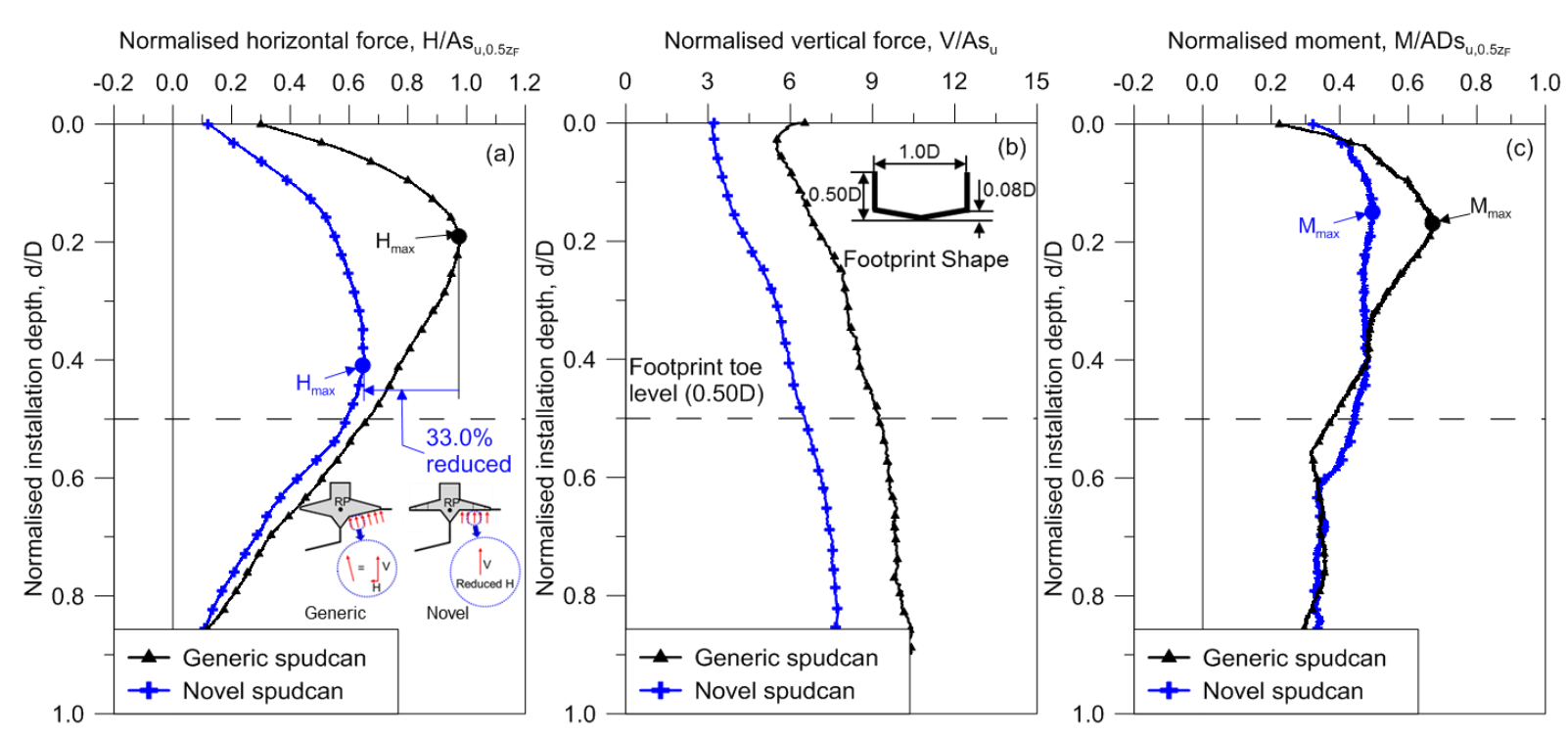

Figure 9. Responses for footprint-spudcan interaction in a deep footprint $200 \mathrm{~g}$ (Test 5 and Test $6 ; \mathrm{D}_{\mathrm{F}}=1.0 \mathrm{D}, \mathrm{z}_{\mathrm{F}}=0.50 \mathrm{D}, \beta=$ 0.50D; Table 2): (a) Normalised horizontal force; (b) Normalised vertical force; (c) Normalised moment.

employed in Test 5 and Test 6 . The potential cavity collapse was prevented by using a very light weight plastic collar with 60 (outer diameter, $\left.\mathrm{D}_{\text {collar }}\right) \times 35$ (height, $\mathrm{h}_{\text {collar }}$ ) $\mathrm{mm}$ (see Fig. 8b). The collar weight was minimised to ensure it did not sink into the clay whilst spinning up to $200 \mathrm{~g}$. The collar was removed just before the penetration test. As shown in Figure $8 \mathrm{c}$, no crack or collapse of the edge of the footprint occurred during Test 5 and Test 6.

Figure 9 shows the normalised results from the Tests 5 and 6 . The results show that the $\mathrm{H}$ and $\mathrm{M}$ of the novel spudcan were also reduced at reinstallation with the deep footprint. By comparing with the results in Figure 7, both horizontal force and moment are higher for the deeper footprint because the balance between left and right side of a spudcan is delayed. The normalised horizontal force along with footprint depths are summarised in Table 4. The results confirm that the novel spudcan is effective at mitigating spudcan-footprint interactions.

Table. 4 Summary of normalised horizontal forces.

\begin{tabular}{llll}
\hline Footprint depth & \multicolumn{3}{c}{$\left(\mathrm{H} / \mathrm{As}_{\mathrm{u}, 0.5 \mathrm{zF}}\right)_{\max }$} \\
\cline { 2 - 4 } & Generic & Novel & Reduction \\
\hline Shallow footprint $(200 \mathrm{~g})$ & 0.41 & 0.22 & $40.3 \%$ \\
Deep footprint $(1 \mathrm{~g})$ & 0.87 & 0.52 & $46.5 \%$ \\
Deep footprint $(200 \mathrm{~g})$ & 0.98 & 0.64 & $33.0 \%$ \\
\hline
\end{tabular}

\section{CONCLUSION}

This paper presented the results from $1 \mathrm{~g}$ and $200 \mathrm{~g}$ centrifuge tests on a generic and a novel spudcans penetrating adjacent to an existing footprint. The artificial shallow and deep footprints were created. The spudcans were penetrated at an offset of 0.50D or $0.55 \mathrm{D}$ from the footprint centre. The results showed that the novel spudcan provides an effective measure at reducing horizontal force and easing the spudcan interaction with footprint. More extensive investigations are being carried out through numerical analyses and centrifuge model tests, with the objective for realistic conditions - global jack-up rig effect, remolded soil strength with penetration and extraction of a spudcan.

Collapse of footprint/cavity at elevated gravity spinning and corresponding prevention using a light weight plastic collar may be helpful for future centrifuge modellers.

\section{ACKNOWLEDGMENTS}

The research presented herein was undertaken with support from the Australian Research Council (ARC) through the Linkage Project LP140100066. The work forms part of the activities of the Centre for Offshore Foundation Systems (COFS), currently supported as a node of the Australian Research Council Centre of Excellence for Geotechnical Science and Engineering and as a Centre of Excellence by the Lloyd's Register Foundation. This support is gratefully acknowledged.

\section{REFERENCES}

Brennan, R., Diana, H., Stonor, R.W.P., Hoyle, M.J.R., Cheng, C.P., Martin, D. \& Roper, R. 2006. Installing jackups in punch through-sensitive clays. Proc. Offshore Technology Conference, Houston, 1-4 May 2006: OTC 18268.

Britto, A.M. \& Kusakabe, O. 1982. Stability of unsupported axisymmetric excavations in soft clay. Géotechnique, 32(3): 261-270.

Britto, A.M. \& Kusakabe, O. 1983. Stability of axisymmetric excavations in clays. Journal of Geotechnical and Geoenvironmental Engineering, ASCE 109(5): 666-681.

Cassidy, M.J., Quah, C.K. \& Foo, K.S. 2009. Experimental investigation of the reinstallation of spudcan footings close to existing footprints. Journal of Geotechnical and Geoenvironmental Engineering, ASCE 135(4): 474-486. 
Cassidy, M.J. 2012. Experimental observations of the penetration of spudcan footings in silt. Géotechnique, 62(8): 727732.

CLAROM. 1993. Design guidance for offshore structures. Club pour les Actions de Recherches sur les Ouvrages en Mer, Eds: Le Tirant, P. \& Pérol, C., Paris.

Erbrich, C.T., Amodio, A., Krisdani, H., Lam, S.Y., Xu, X. \& Tho, K.K. 2015. Re-visiting Yolla- new insight on spudcan penetration. Proc.15th International Conference on the Jack-up Platform Design, Construction and Operation, London.

Finnie, I.M.S. \& Randolph, M.F. 1994. Punch-through and liquefaction induced failure of shallow foundations on calcareous sediments. Proc. International Conference on Behaviour of Offshore Structures, Boston, 12-15 July: 217 -230.

Gan, C.T., Leung, C.F. \& Chow, Y.K. 2008. A study on spudcan footprint interaction. Proc. of the 2 nd BGA International Conference on Foundations, Dundee, 24-27 June 2008: 861-872.

Gan, C.T., Leung, C.F., Cassidy, M.J., Gaudin, C., Chow, Y.K. 2012. Effect of time on spudcan-footprint interaction in clay. Géotechnique, 62(5): 401-413.

Gaudin, C., Cassidy, M.J., Donovan, T., Grammatikopoulou, A., Jardine, R.J., Kovacevic, N., Potts, D.M., Hoyle, M.J. R. \& Hampson, K.M. 2007. Spudcan reinstallation near existing footprints. Proc. 6th International Conference of Offshore Site Investigation and Geotechinics, London, 1 Feb. 2007: 285-292.

Handidjaja, P., Gan, C.T., Leung, C.F. \& Chow, Y.K. 2009. Jack-up foundation performance over spudcan footprints analysis of a case history. Proc. 12th International Conference on the Jack-up Platform Design, Construction and Operation, London, 15-16 Sept. 2009.

Hossain, M.S. \& Dong, X. 2014. Extraction of spudcan foundations in single and multilayer soils. Journal of Geotechnical and Geoenvironmental Engineering, ASCE 140(1), 170-184.

Hunt, J.R. \& Marsh, D.P. 2004. Opportunities to improve the operational and technical management of jack-up deployments. Marine Structures, 17: 261-273.

InSafeJIP. 2010. Improved guidelines for the prediction of geotechnical performance of spudcan foundations during installation and removal of jack-up units. Joint Industry Funded Project.

ISO. 2012. Petroleum and natural gas industries - Site specific assessment of mobile offshore units. Part 1: Jack-ups. International Organization for Standardization, ISO 19905-1.

Jack, R.L., Hoyle, M.J.R., Smith, N.P. \& Hunt, R.J. 2013. Jack-up accident statistics - a further update. Proc. 14th International Conference on the Jack-up Platform Design, Construction and Operation, London, 17-18 Sept. 2013.

Jun, M.J., Kim, Y.H., Hossain, M.S., Cassidy, M.J., Hu, Y. \& Sim, J.U. 2017a. Optimising spudcan shape for mitigating spudcan-footprint interaction. Canadian Geotechnical Journal, submitted 24 July 2017.

Jun, M.J., Kim, Y.H., Hossain, M.S., Cassidy, M.J., Hu, Y., Shim, J.U. 2017b. Physical and numerical modelling of novel spudcans for easing footprint-spudcan interaction issues. Proc. $19^{\text {th }}$ International Conference on Soil Mechanics and Geotechnical Engineering, Seoul, 17-21 Sept. 2017: 2297-2300.

Jun, M.J., Kim, Y.H., Hossain, M.S., Cassidy, M.J., Hu, Y., Shim, J.U. 2018. Numerical investigation of novel spudcan shapes for easing spudcan-footprint interactions. Journal of Geotechnical and Geoenvironmental Engineering, American Society of Civil Engineers, Accepted.

Killalea, M. 2002. Jackup footprint, punch through studies underway. Drilling Contractor: 43.
Kong, V.W. 2012. Jack-up reinstallation near existing footprints. Ph.D. thesis, University of Western Australia, Australia.

Kong, V.W., Cassidy, M.J. \& Gaudin, C. 2013. Experimental study of the effect of geometry on reinstallation of jack-up next to footprint. Canadian Geotechnical Journal, 50(5): 557-573.

Leung, C.F., Gan, C.T. \& Chow, Y.K. 2007. Shear strength changes within jack-up spudcan footprint. Proc. 17th International Offshore and Polar Engineering Conference, Lisbon, 1-6 July 2007: 1504-1509.

Menzies, D. \& Roper, R. 2008. Comparison of jackup rig spudcan penetration methods in clay. Proc. 40th Offshore Technology Conference, Houston, 5-8 May 2008: OTC 19545.

Meyerhof, G.G. 1972. Stability of slurry trench cuts in saturated clay. Proc. Speciality Conf. on Performance of Earth and Earth Supported Structures, 1: 1451-1466.

Osborne, J.J. \& Paisley, J.M. 2002. S E Asia jack-up punchthrough: the way forward? Proc. Offshore Site Investigation and Geotechnics - Diversity and Sustainability, London, 26-28 Nov. 2002: 301-306.

Osborne, J.J. 2005. Are we good or are we lucky? Presentation Slides for OGP/CORE Workshop: The Jackup Drilling Option- Ingredients for Success, Singapore, 27-28 Oct. 2005.

Randolph, M.F., Cassidy, M.J., Gourvenec, S. \& Erbrich, C.J. 2005. Challenges of offshore geotechnical engineering. State of the Art paper, Proc. International Conference on the 16th Soil Mechanics Soil Mechanics and Geotechnical Engineering, Osaka, 12-16 Sept. 2005, 1: 123-176.

Stewart, D.P. 1992. Lateral loading of piled bridge abutments due to embankment construction. Ph.D. thesis, University of Western Australia, Perth, Australia.

Teh, K.L., Handidjaja, P., Leung, C.F. \& Chow, Y.K. 2010. Leg penetration analysis of jack-up rig installation over existing footprints. Proc. 20th International Offshore and Polar Engineering Conference, Beijing, 2, 427-433.

Zhang, W., Cassidy, M.J., and Tian, Y. 2015. 3D large deformation finite element analyses o jack-up reinstallations near idealised footprints. Proc. International Conference on the 15th Jack-up Platform Design, Construction and Operation, London 